\title{
Study Of Law Number 9 Off Regarding Freedom Of Speech In Publice
}

\author{
Ali Azhar, KMS Novyar Satriawan
}

\begin{abstract}
Student demonstration is an expression of expressing an opinion or idea. Demonstrations are expected to improve social life because they are not as expected. holding demonstrations can end up being anarchist and out of control, despite strict rules. This study was conducted for the implementation of student demonstrations in the city of Indragiri Hilir Regency with Law No. 9 of 1998 concerning Freedom of Expression in the Public with a sociological approach. The results of the analysis in this article found that demonstrations by students in the town of Indragiri Hilir Regency were not yet effective according to Law No. 9 of 1998. Students did not notify the demonstration plan to the police, demonstrations that exceed the specified time limit, student demonstrations turned into naughty and tend to be anarchist. The obstacles encountered in carrying out the demonstration were due to time constraints in expressing their opinions in public, and the demonstration did not follow the rules of reporting the action plan, rough security was not responsible for the intervention of the security forces. resulting in physical conflict, securing abusive acts, and destructive / confiscation / takeover of actions.
\end{abstract}

Keywords : Demonstrations, Public Opinions, Students.

\section{INTRODUCTION}

Law Number 9 of 1998 regulates Freedom of Expressing Opinions in Public. Article 3 of the law states that its implementation must fulfill several principles, namely the principle of balance between rights and obligations, the principle of deliberation and consensus, the principle of legal certainty and justice, the principle of proportionality, and the principle of benefits. These principles form the basis of freedom which is responsible for public opinion. The enactment of this law does not guarantee the implementation of demonstrations to be orderly.[1] These five determinants can be anticipated well to avoid mass unrest. Demonstrations can be done with thoughts in verbal, written and so on in a demonstrative manner in public which is done in an orderly or not. Form channels / open spaces either formally through the People's Representative Council (DRD) / Regional People's Representative Council (DPRD). However, the rise of public opinion submission with demonstrations taking to the streets is preferred by the public in expressing demands / aspirations. Freedom of expression in public is a human right guaranteed by the 1945 Constitution of the Republic of Indonesia and the Universal Declaration of Human Rights. Expression of opinion in public is the embodiment of democracy in the order of life of society, nation and state. In relation to efforts to build a democratic country, it is also necessary to have a safe, orderly and peaceful atmosphere that does not harm the interests and other human rights. In terms of safeguarding the demonstration, the enactment of Law No. 2 of 2002 concerning the Indonesian National Police has implications for the paradigm shift of the Indonesian National Police[2]. The National Police are demanded not to prioritize repressive actions but rather persuasive and preventive actions. The main tasks and authority of the National Police as mentioned in Article 13 of Law Number 2 of 2002 concerning the Police of the Republic of Indonesia include: a. Maintaining public security and order. b. Uphold the law. c. Provide protection, protection and service to the community.

- Ali Azhar. Universitas Islam Indragiri. Low Faculty. E-mail: sahabat.aliazhar@gmail.com.

- KMS Novyar Satriawan. Universitas Islam Indragiri. Low Faculty. Email : novyarsatriawan3@gmail.com.: author_name@mail.com (This information is optional; change it according to your need.)
Demonstrations can be said to be safe, orderly and peaceful if the implementation process does not cause events or activities that violate the applicable legal rules and does not cause actions that can interfere with the security and involvement of the community. The Police Agency has prepared security measures with the issuance of Decree of the National Police Chief Number Pol: Skep / 1600 / X / 1998 and Decree of the Director of Samapta Babinkam Polri Police Number: Proptap / 01 / V / 2004. Securing demonstrations conducted by the National Police is not just securing places and protesters, but more than that securing the general public environment [3]. The procedure for conducting the conveyance in advance has actually been strictly regulated, but in practice many of the provisions were not met / violated by the demonstration participants, for example not being fulfilled at the time of notification, not informing the local Police, the demonstration activities were not in accordance with the notification letter ( both from the route, time, length, props taken and the number of participants). Based on observations made by the author of the implementation of student domonstration in Indragiri Hilir Regency not in accordance with the provisions contained in Law No. 9 of 1998 which tends to result in traffic jams, riots, anarchists, and so on as in demonstrations of increases in fuel oil (BBM) and elections Regional Head (Pilkada).

\section{RESEARCH METHODS}

This type of research is a sociological law research with research location in Indragiri Hilir Regency. The reason for determining the location was based on the consideration that the Regency of Indragiri Hilir was the city that had the most frequent student demonstrations compared to the districts / cities in Riau Province. The research sample determined was the Chief of Police Ops Sat Intelkam Polresta Indragiri Hilir Regency amounted to 1 person, BEM Management of state universities and private universities in Indragiri Hilir Regency amounted to 1 person at each university consisting.

The data in this study consisted of 1) primary data, i.e. data obtained from the field determined in the sample, secondary data, i.e. data obtained through several literatures and various laws and regulations, and 3) tertiary data, i.e. data obtained through dictionaries and exemplopedias. Data collection techniques in this study using observation by direct observation of the object of research, interviews with respondents, and literature review analyzes a variety of 
literature that has a correlation with the problem being studied. Data analysis uses qualitative analysis by describing descriptively from the data that has been obtained. The conclusions of the results of the study used an inductive method concerning the legal aspects of the implementation of student demonstrations in Indragiri Hilir Regency. Inductive method is to draw a conclusion of a statement or proposition that is specific to a statement or proposition that is general [4].

\section{DISCUSSION}

\subsection{The substance of the demonstration as the delivery of ideas}

Demonstration is a protest movement by taking to the streets. Demonstrations come from two syllables, namely the word demo (demonstration) and the word concentration (concentration of mind or thought on a matter, or concentration of energy, strength, forces, etc. in one place) merge into one single word, namely demonstration. Demonstrations can also be interpreted as an action in the form of a demonstration carried out by the concentration of an issue. Therefore, there is no guarantee that the demonstration will disappear automatically when the system has been arranged in such a way. Because, attraction of interests will always decorate the life of the nation and state. In addition, demonstrations can be a means of controlling power, namely as a check and balance force, as a balancing force, so that there is no destructive inequality. The Constitution highly respects and gives a suitable place for people who want to hold demonstrations in public spaces. The follow-up of the constitution was more outlined in the rules at the level of the law, namely Law Number 9 of 1998 concerning Freedom of Expressing Opinions in Public. Demonstration is a media and a means of conveying ideas or ideas that are considered true and trying to publish them in the form of mass direction. Demonstration is also a means or tool that is closely related to the purpose of the use of the facility or tool and how it is used. Demonstrations are actions to express rejection, criticism, impartiality, and rejection of things that are considered a deviation. Article 1 Paragraph (2) of Law Number 9 of 1998 concerning Independence Expressing Public Opinion defines that a demonstration is an activity carried out by one or more persons to express their thoughts. Submission of public opinion must be carried out in accordance with several principles in Article 3 of Law Number 9 of 1998 concerning Freedom of Expressing Opinion in Public: 1) The principle of balance between rights and obligations; 2) The principle of deliberation and consensus; 3 ) The principle of legal certainty and justice; 4) The principle of proportionality; and 5) Principle of benefit. These five principles are the foundation of freedom which is responsible for thinking and acting to express opinions in public. Demonstrations are not as narrow as most people understand by long-marching, shouting, burning tires, theatrical actions, damaging fences, or actions that have been attached to the word demonstration. The place is public open space which can be seen by the public in general or overt. Demonstrations can be positive, but can also be negative. When the demonstration upholds democracy, it is seen as positive and has value in the eyes of society. However, when a demonstration ignores democracy then it is seen as a negative thing. Demonstration is a way of conveying thoughts or opinions that must be maintained and maintained so as not to turn into negative goals.

\subsection{Legal Protection of Freedom of Expression in Public}

Demonstrations or demonstrations are included in human rights that must be protected. In the body of the 1945 Constitution, human rights principles are spelled out, such as:

1. Equal status of citizens in law and government (Article 27 Paragraph (1).

2. The right to decent work and livelihood (Article 27 Paragraph (2).

3. Freedom of association and assembly (Article 28).

4. The right to express thoughts verbally or in writing (Article 28).

5. Freedom to embrace religion and worship in accordance with that religion and belief (Article 29 Paragraph (2)).

6. Right to education and teaching (Article 31 Paragraph (1)

Freedom of expression in public is guaranteed in the 1945 Constitution Article 28, 28 E Paragraph (3), Decree of the Indonesian People's Consultative Assembly (MPR) No. XVSII / MPR / 1998 concerning Human Rights Articles 14, 19, 20 and 21, Universal Declaration of Human Rights Article 19, Law Number 9 of 1998 concerning Independence Expressing Opinions in Public and Law Number 39 of the Year 1999 concerning Human Rights Article 14, 23 Paragraph (2) and Article 25. Demonstrations or rallies are one form of expression of public opinion and are part of the manifestation of democracy adopted by the Indonesian people. Demonstration is also a means or tool that is closely related to the purpose of the use of the facility or tool and how it is used. Demonstration or democracy is seen as a form of aggressive behavior, especially the aggressive behavior of the masses that arises as a result of frustration in the community that occurs due to a mismatch between reasonable expectations with the reality obtained (relative deprivation). Demonstration or democracy is seen as a form of aggressive behavior, especially the aggressive behavior of the masses that arises as a result of frustration in the community that occurs due to a mismatch between reasonable expectations with the reality obtained (relative deprivation). In addition, the demonstration is seen as a collective action in which there are several groups of people who are very potential and easily invited to conduct demonstrations, including the poor, people who are experiencing frustration, people who are dissatisfied, people who are excluded, young age groups, as well marginal groups in society. Demonstrations must be carried out peacefully and not disturb public order, so that what is conveyed can be heard by the general public both the public, authorities, officials, and the country's political elite. In addition, the demonstration is seen as a collective action in which there are several groups of people who are very potential and easily invited to conduct demonstrations, including the poor, people who are experiencing frustration, people who are dissatisfied, people who are excluded, young age groups, as well marginal groups in society. Demonstrations that develop and take place in various areas both carried out by the community, NonGovernmental Organizations, Community Organizations, Political Parties, and students often lead to anarchism and chaos. Demonstrations can be an enlightenment to problems that develop by carrying out the voices of critical, aspirational and solutive aspirations that represent all the common desires and hopes for a country's progress and good. However, the demonstration at this time was beyond the expectations of the community. Demonstrations no longer provide solutions, but instead bring new problems. Demonstrations carried out by 
several students both state and private universities tend to be disorderly and lead to anarchism. This fact is a bad precedent and counter-productive to the vision of the demonstrators' struggle because it harms various parties. This condition can be seen from the anarchist attitude of the masses which damages various infrastructure facilities and disturbs public order, such as blocking roads that interfere with public transportation, burning old tires, spreading banners, photographs, flags, damaging fences, and various other public facilities.

\subsection{Indragiri Hilir Regency Student Demonstration Implementation Based on Law Number 9 of 1998 concerning Independence Expressing Opinion in Public}

Freedom of opinion is guaranteed basically in the constitution and legislation in force. Demonstration as a manifestation of freedom of opinion is one of the human rights 11 regulated in Law Number 9 of 1998 concerning Freedom of Expression in Public. The law regulates the forms and procedure for public opinion submission. Article 9 Paragraph (1) of Law Number 9 of 1998 states that the form of public opinion submission can be carried out with: a. Demonstration or demonstration; $b$. Parade; c. General meeting; and / or d. Free pulpit. Furthermore, Article 9 Paragraph (2) of the same law states that the submission of an opinion in public as referred to in Paragraph (1), is carried out in places open to the public, except: a. within the presidential palace, places of worship, military installations, hospitals, airports or seaports, train stations, land transportation terminals. b. national vital objects. c. on national holidays. Article 9 Paragraph (3) states that the perpetrator or participant submits his opinion in public as referred to in paragraph (1) is prohibited from carrying objects that could endanger public safety. Article 10 Paragraph (1) Law Number 9 of 1998 concerning Freedom of Expressing Public Opinions states that the submission of an opinion in public as referred to in Article 9 must be notified in writing to the National Police. Article 10 Paragraph (2) states that written notice as referred to in Paragraph (1), is submitted by the person concerned, leader, or person in charge of the group[5]. Article 10 Paragraph (3) of Law Number 9 Year 1998 concerning Freedom of Public Opinion states that the Notification as referred to in paragraph (1) no later than $3 \times 24$ hours before the commencement of activities has been received by the local police. Article 10 Paragraph (4) states that the written notification referred to in paragraph (1) does not apply to scientific activities on campus and religious activities[2],[6]. Article 11 of Law Number 9 Year 1998 concerning Independence of Expressing Opinion in Public states that "Notification letter as referred to in Article 10 Paragraph (1) contains a. purpose and objectives; b. place, location and route; c. time and time; d. Shape; e. Person in charge; $f$. the name and address of the organization, group or individual; g. props used; and / or h. number of participants. Article 12 Paragraph (1) of Law Number 9 of 1998 concerning Independence in Expressing Public Opinion states that the person in charge of the activities referred to in Article 6. Article 9 and Article 11 shall be responsible for making these activities carried out safely, orderly and safely. Article 12 Paragraph (2) states that for up to 100 (one hundred) perpetrators or participants in demonstrations or demonstrations and marches, there must be up to five people responsible. Based on the results of the interviews showed that the implementation of demonstrations by students of Indragiri Hilir Regency was not in accordance with Law Number 9 of 1998 concerning Freedom of Expression of Public Opinion. In general, participants in the demonstration activities did not understand the rules set out in the law[7]. Samino as a Member of Commission 1 of the Regional Representative Council (DPRD) of Indragiri Hilir Regency argued that "strongly agreed to the specific requirements and procedures for demonstrations or demonstrations. He reasoned that the demonstration could proceed in an orderly manner ". Head of Operations Development Guidance (Kaur Bin Ops Sat), intelligence officer of Indragiri Hilir Regency Police explained "there are certain procedures for carrying out demonstrations. According to him the demonstration is the right of every citizen and has protected these freedoms in law. However, there are certain procedures contained in the law aimed at limiting rights so as not to harm or violate the rights of others "[8]. With regard to the arrangement of the form, procedure, and responsibility for the implementation of public opinion as stipulated in Law Number 9 of 1998 concerning Freedom of Expressing Opinion in Public, the respondents agreed with the arrangement. It's just that there were many participants in the activity that obeyed the rules. Rudi, Minister of Social and Political Student Executive Board (BEM) of the Islamic University of Indragiri, Indragiri Hilir Regency welcomed the regulation of the demonstration. According to Rudi, "the existence of these arrangements aims to ensure that every demonstration runs well and regularly". During this time many student demonstrations that run anarchist. However, this arrangement should not restrain students from carrying out demonstrations. Muhammad Syarif as Secretary of the Cabinet of the Student Executive Board (BEM) of the Riau Islamic University said that "as long as the arrangement is not biased and for the common good it needs to be welcomed and give appreciation to the arrangement. Because, this arrangement will direct the demonstration to be better ". Indragiri Hilir Regency DPRD should be able to monitor the effectiveness of the implementation of the regulation. As long as the participants of the activity carry out the procedures set out in the law, the demonstration will certainly be able to run well, so that students' ideas can be conveyed and the community can accept the action with a positive value ".Student demonstrations certainly respect the rights of others, respect moral rules that are generally recognized, obey applicable laws and maintain public order and security. Student maturity can actually be seen in whether the activities carried out are well planned or not. Demonstration as a way of expressing opinions, of course students must obey the existing rules, so that demonstrations can benefit. In line with Rudi, Cabinet secretary of the Student Executive Board (BEM) of the Indragiri of Islamic University in Riau explained that basically every student demonstration starting from the intention for the common good by responding to policies that are not in line with the aspirations of the people[8]. In the author's observation that most of the student demonstrations went in an orderly manner, while a small proportion of student demonstrations violated the rules. This fact occurs because of misunderstandings between demonstrators and security forces, provocation, because of intervention, and so on. The author is of the opinion that it is best for the security party responsible for the security of the demonstration to anticipate possible actions carried out outside the applicable procedures[9]. Chief of the Bin Ops Sat Intelligence of the 
Indragiri Hilir Regency Police believes that "students who will conduct demonstrations are required to give their activities to the police within $3 \times 24$ hours. The goal is to find out about the form of activities, objectives, tools used, the number of masses, and who is the field coordinator. In carrying out demonstrations students do not understand the rules such as not carrying out demonstrations on holidays, do not carry out demonstrations in the place of vital objects, public facilities, such as airports, hospitals, military authority areas, etc. " Students who will carry out demonstrations must pay attention to public order. Demonstrations carried out by students should run orderly and smoothly. Demonstrations carried out by students tend to pay less attention to applicable legal provisions. During demonstrations, students sometimes block roads which cause congestion. Furthermore, students give speeches by issuing words that insult the state apparatus, even though this is relatively small. In addition, the demonstration that was held once ended in an orderly manner (ie anarchist), namely in 2019. The fact above was regretted by Rudi explaining that "the incident occurred because there were provocateurs who provoked students" . A similar statement was also conveyed by Mellia as Head of Organization and Politics of the University Islam of Indragiri stating that "the police should have restrained themselves while securing demonstrations college student"[10]. Rudi considered that the demonstration carried out by students had not been carried out with the procedures in Law No. 9 of 1998 concerning Freedom of Expressing Opinion in Public. If it is carried out according to procedure, certainly there will be no demonstrations that lead to anarchism. Rudi noted that Law Number 9 Year 1998 had not been effective. According to him, "students who took part in the demonstration had experienced difficulties from the police. The police banned the student demonstrations just because they wanted to secure the location. It is clear that students are having difficulty expressing their opinions in public ". Second, there is an intervention from both the intelligence and certain parties who do not want a demonstration. In addition, there are threats to the demonstration action plan, even the abduction of demonstrators who will carry out the demonstration [1]".

\subsection{Obstacles to the Implementation of Indragiri Hilir Regency Student Demonstrations}

The implementation of student demonstrations in Indragiri Hilir Regency based on Law Number 9 of 1998 concerning Freedom of Expressing Public Opinions there are several obstacles. These obstacles include: First, the time limit for the demonstration. Second, the responsibility for the security of demonstrations has not been carried out properly. Third, the security forces are too harsh. Rudi stated that "the time limitation for demonstrations triggers an orderly demonstration. Plus there are still many police officers who do not understand Law Number 9 of 1998 concerning Freedom of Expressing Opinions in Public ". According to him, "most of the field coordinators (korlap) demonstrations did not follow the rules for reporting action plans, so the police did not issue demonstration permits. Students often assume that after giving a notification letter within $1 \times 12$ hours before its implementation, their obligations have been fulfilled. In the demonstration, the Korlap must maintain that the demonstration goes orderly and not anarchist ". In terms of the security responsibility of the demonstration, it seems that it has not been carried out properly. Rudi considered that the police had not fully carried out the responsibility of carrying out the security of student demonstrations properly and correctlyst[11]. A year ago there were incidents of clashes between students and the police at the Radio Senada FM. However, the security measures carried out by the police have not been appropriate and not as they should be. Even the police sometimes intervene or threat, such as by telephone, sms, or meet in person. In addition, the security carried out by the police is excessive. The incident of clashes between students and the police, it was proven that there were police officers who carried out beatings with clubs for mass student demonstrations. In fact, the mass demonstrations of students do not have weapons. There were even police officers who beat and evicted students who were praying at the mosque in the Radio Senada FM office. Another obstacle found was that the security forces were too harsh. "intervention from security or intelligence, provocation, officials or targets of action disappeared, misunderstanding between the mass of demonstrations with the security forces, resulting in physical conflict, security of violent actions, destruction / confiscation / confiscation / seizure of props of action, such as toa, speakers, and security in a way that is irresponsible ".Efforts to Overcome Obstacles in the Implementation of Indragiri Hilir Regency Student Demonstrations Review of Law Number 9 of 1998 concerning Independence Expressing Opinions in Public. There are several efforts that must be made to overcome the obstacles in the implementation of student demonstrations in Indragiri Hilir Regency. First, increasing students' understanding of Law No. 9 of 1998 concerning Freedom of Expression in Public. Second, increased security carried out by the police. Third, sufficient funding. Fourth, the application of clear and binding legal rules. Fifth, intense coordination and communication between students, the police and government. The first effort is to increase students' understanding of Law No. 9 of 1998 concerning Freedom of Expression in Public[12]. The aim was to increase student understanding of the substance contained in Law Number 9 of 1998 concerning Freedom of Expressing Opinions in Public. Rudi agrees with this opinion. According to Rudi, "students who will carry out demonstrations must understand Law No. 9 of 1998 concerning Freedom of Expression in Public. The aim is for the demonstration to run in an orderly and orderly manner. [13]" The second effort is to increase security by the police. With regard to the security measures carried out by the police, Rudi stated that in order to secure student demonstrations, the police must monitor the demonstrations and the conditions of the masses. The third effort is sufficient funding. Chief of the Bin Ops Sat Intelligence of the Indragiri Hilir Regency Police argues that "every security requires sufficient funds. During this time the operational funds to protect the demonstration have not been sufficient. Therefore, it is necessary to have optimal budget support for every demonstration safeguard. "The fourth effort is the application of clear and binding legal rules. Chief of the Bin Ops Sat Intelligence of the Indragiri Hilir Regency Police argues that "there needs to be clear and binding legal rules for unauthorized demonstrations. In addition, there is a need for criminal sanctions against student demonstrations that act in violation of applicable legal provisions. Students must follow applicable legal norms and obey them. The aim is to make the demonstration run safely and not anarchist ". The fifth effort is intense coordination and communication between students and the police. Chief of the Bin Ops Sat Intelligence of the 
Indragiri Hilir Regency Police explained that "the Korlap needs to coordinate openly with the police regarding the number of masses, the equipment carried, and the purpose of the demonstration, and to have good cooperation with government agencies"[10]. In carrying out demonstrations students must convey the purpose of the demonstration well to the target. Rudi explained that "there needs to be intense coordination and communication between the students and the police, getting used to orderly carrying out demonstrations to improve action management, conflict management, and other things that are supportive, carry out field techniques (teklap) well, function the general coordinator (cordon), korlap, and structure of action properly, and prepare a creative personality, innovative, and uphold applicable regulation".

\section{CONCLUSION}

Based on the analysis in the above discussion it can be concluded as follows:

1. Orderliness of students demonstrating in Indragiri Hilir Regency has not been effective according to Law Number 9 of 1998 concerning Freedom of Expressing Opinion in Public. Students tend not to notify the police demonstration action plan, student demonstrations over the time limit determined by the applicable laws and regulations, student demonstrations turn out in an orderly manner and tend to be anarchist, and so on.

2. Efforts that must be made in overcoming these obstacles are socialization or legal counseling of Law Number 9 of 1998 concerning Freedom of Expressing Public Admission to students in Indragiri Hilir Regency so that they understand the substance of the regulation, the police must understand the conditions student demonstrations, sufficient funding, and clear and binding legal rules.

\section{REFFERENCE}

[1] C. Lin, "Student Rights and Human Rights Education Taiwan's Experience," pp. 73-83, 1999.

[2] and V. S. Katrina Dial, Diana Riddley, Kiesha Williams, "A demonstration to help students understand the law of conservation of mass," vol. 12, 2006.

[3] K. N. SATRIAWAN and ISDARWANTO, "Pasal 2 Bab II Peraturan Daerah Kabupaten Indragiri Hulu Nomor 12 Tahun 2004 Tentang Hiburan Umum," 2004.

[4] H. Students, "Responding to Student Demonstrations and Protests in Schools and School Districts," vol. 24, pp. 18, 2018.

[5] Sarip, "PEMIKIRAN THE KING CAN DO NOT WRONG DALAM POLITIK HUKUM KETATANEGARAAN INDONESIA," Kanun J. Ilmu Huk., vol. 20, no. 2, pp. 316-336, 2018.

[6] N. Huda, "Hak Prerogatif Presiden dalam Perspektif Hukum Tata Negara Indonesia."

[7] M. H. Guslina, HB, "POLA PERLINDUNGAN HUTAN ADAT TERHADAP MASYARAKAT ADAT DI PROVINSI RIAU PASCA PUTUSAN MAHKAMAH KONSTITUSI NOMOR 35/PUU-X/2012," vol. 16, no. 1, pp. 183-200, 2016.

[8] J. Asshiddiqie, "KEDUDUKAN DAN PERANAN HUKUM TAT A NEGARA DALAM PEMBANGUNAN ' Jimly Asshiddiqie," pp. 135-153, 1995.

[9] J. Hasse, "Anarkisme Demonstrasi Mahasiswa: Studi Kasus Pada Universitas Islam Negeri Alauddin Makassar," pp. 49-70, 2012.
[10] R. Stuckey, Best Practices for Legal Education Best Practices for Legal Education. .

[11] Andrizal, "DEMONSTRASI MAHASISWA DI KOTA PEKANBARU BERDASARKAN UNDANG-UNDANG NOMOR 9 TAHUN 1998 TENTANG KEBEBASAN," no. 9, pp. 120-134, 1998.

[12] N. Evanty, "URGENSI UNDANG-UNDANG BATAS WILAYAH."

[13] L. T. Muharlisiani et al., "Public Relations Management Through Management By Objective," vol. 8, no. 10, pp. 1993-1997, 2019. 